\title{
Micro Entreprise Empowerment Model Through Islamic Financial Service Cooperative (Study in Indonesia-Malaysia)
}

\section{Sri Herianingrum¹, Muhammad Syukri Salleh², and Ririn Tri Ratnasarí1}

${ }^{1}$ Faculty of Economic and Bussiness Universitas Airlangga, Jln. Airlangga 4-6, 60286, Surabaya, Indonesia

${ }^{2}$ Islamic Economic Development, Universiti Sains Malaysia, 11800 USM Penang, Malaysia

\section{Abstract}

Micro-enterprise is a business that dominating the economy of Indonesia and Malaysia. The main problem faced by micro businesses is the issue of capital. The existence of Islamic financial service cooperative is expected to solve the problems of capital for micro-enterprises. Based on these descriptions then this study wanted to exercise how the empowerment model of micro enterprises implemented through enterpreneurs empowerment by Islamic financial service cooperative (IFSC). This study used qualitative

Corresponding Author:

Sri Herianingrum

sri.herianingrum@feb.unair.ac.id

Received: 10 February 2019

Accepted: 14 March 2019

Published: 28 March 2019

Publishing services provided by

Knowledge E

(c) Sri Herianingrum et al. This article is distributed under the terms of the Creative Commons Attribution License, which permits unrestricted use and redistribution provided that the original author and source are credited.

Selection and Peer-review under the responsibility of the ICIEBP Conference Committee.

\section{G OPEN ACCESS} methods to explore micro enterprises empowerment in order to get a micro business empowerment model. Both in Indonesia as well as Malaysia empowering micro businesses by IFSC appears from its ability to obtain capital, able to motivate the group, and was able to get access to the Government. The difference is in the intensity of the attention of the Government, the Government of Malaysia more intense attention on micro enterprises, so that micro enterprises more easily get access to the goverment and other financial institutions.

Type of Paper: Empirical

Keywords: Micro Entreprise; Islamic Financial; Service Cooperative; Empowerment, Model

\section{Introduction}

In majorities of the provinces in Indonesia and Malaysia, the government strongly supports the development of Islamic economics. The problems encountered in the implementation of Islamic economic is how the Islamic economic is able to build the economy mainly through micro enterprise. While contributing to the economy of Islamic economics both on the national and regional levels are still relatively small. Microenterprise is a business that dominate the economy of Indonesia and Malaysia. The main problem faced by micro businesses is the issue of capital. The existence of Islamic 
Financial Service Cooperative is expected to solve the problems of capital for microenterprises.

Economic development of Islam among other tangible presence of Islamic micro finance institutions. According to Sudarsono (2007: 96), Islamic Financial Service Cooperative is the economic organization of society which aims to support the economic activities of the people below the small and run by Islamic law. Economic development of Islam among other tangible presence of Islamic micro finance institutions. According to Sudarsono (2007: 96), Islamic Financial Service Cooperative is the economic organization of society which aims to support the economic activities of the people below the small and run by Islamic law.

Islamic financial service cooperative has a very important role in empowering micro, and the main problem faced by the micro, among others, is the problem of capital. The purpose of Islamic financing that carried out by Islamic financial service cooperative is to increase the development of mustahiq or micro enterprises run by customers that can be seen from several factors: the customer's business success with increased sales revenues and also after obtaining of financing that can be said to be capable of increasing micro enterprises.

Sutawi (2008) argue that problems capital micro businesses need to be examined as to how the role of Islamic financial service cooperative in enterpreneur increasing. Islamic Finance Institutions such as Islamic Financial Service Cooperative with profit loss sharing system is an appropriate financing to be channeled to the micro enterprises which is a risky business. An increase Islamic Financial Service Cooperative in financing is expected to increase business development as stated by Grönroos (1990) that the stronger the relationship between small businesses and banks, the performance is good. In the process of channeling financing should be seen Islamic Financial Service Cooperative financing role in developing the business, particularly in the field of microenterprises.

Choudury, et al. (2008) stated the same thing, that micro-businesses that receive loans from financial institutions financing will result in a good performance if the financial institutions do proactive relationship with the business. So after getting venture capital financing is expected Islamic Financial Service Cooperative or effort required means of micro entrepreneurs met so that they are able to improve performance ie facilitate them in performing activities of production to marketing their products in order to achieve operating profit growth.

This study used a qualitative research method, the scope of which is the role of financing Islamic Financial Service Cooperative in developing micro-enterprises. The benefits 
of this research is that it can be used as a constructive input to the parties concerned, in this case the Islamic Financial Service Cooperative, micro entrepreneurs, and government, among others, the Department of Cooperatives and SMEs, and Department of Industry and Commerce. This study was limited to the role of financing in empowering micro businesses to be more focus is discussed, assuming the development of microenterprises are the most prominent value that can be explored. The purpose of this study generate output Islamic development model based on the role of financing of the Islamic Financial Service Cooperative in developing micro-enterprises and the value of the urgency of this research is to examine in depth the success of Islamic Financial Service Cooperative in empowering micro enterprises.

\section{Literature Review}

\subsection{The role of financing of the Islamic financial service coopera- tive in the empowerment of micro enterprises}

Driessen Ende (2006) said that the success achieved by businessmen including small can be seen from the growth of net profit, sales growth (many projects handled), return on investment, ruling the market share (number of relationships). Chan and Chan (2004) says that business success is examined from three perspectives, namely learning and growth, financial, and internal business processes.

Islamic financing is granted are expected to encourage the development of business in the corporate world. According to the Islamic view of business development is not simply material success but also the success of the non material. Performance measures in Islam between are: (1) the profit, in material or non material, (2) growth, (3)sustainability, and (4) increase or means of Allah swt. It is therefore with Islamic financing system to adhere to the results given to micro-entrepreneurs are expected to be able to increase the development of its business, other than a non-profit materials (qimah madiyah) e.g. increased sales results are stable, but also get the benefit of non-oriented material on the qimah insaniyah that is the benefit that is humanity. For example being able to provide wider employment opportunities, especially for labor in the neighborhood around the SMEs stand, as well as the ability to transmit religious obligatory, infaq, shadaqoh, which tends to increase, both conducted by business owners or employees of SMEs.

Other developments in the form of qimah khuluqiyah the noble moral values (akhlaqul karimah) form the basic foothold in managing the company, so Islamic brotherhood 
relationships are created, both among business owners with employees, business owners as well as employees of the customer, to the surrounding communities of SMEs, as well as with government agencies and the private sector working together and doing the coaching of SMEs. Do not forget the other Islamic financial institution partners that help SMEs capital. Other performance indicators is qimah ruhiyah which religious consciousness, which can be seen from the ability of the owners and employees of SMEs in fulfilling our obligation to help orphans, go to Hajj or ' Umrah, and the willingness to share knowledge, or skill against the brothers, colleagues and the general public about tips in achieving the success of the effort, and also his willingness to partner or form a cluster.

\section{Reseach Methodology}

\subsection{Research approach}

To answer the problem formulation used a qualitative research approach by descriptive strategy. The study was conducted with a exploratory deep description holistic understanding, and able to understand the meaning of the issue. A qualitative approach for this study wanted to unveil a model of empowerment. In addition, qualitative approach also gives an opportunity to understand the phenomenon in the view of local actors.

\subsection{The scope of the research}

Referring to the formulation of the problem and research objectives, the scope of the research is aimed at Islamic Financial Service Cooperative and empowerment of micro enterprise-financed by Islamic Financial Service Cooperative in Indonesia and Malaysia. Micro empowerment indicators can be seen from the ability to fulfill administrative requirements, active in business groups, develop a design or technology, modern management, motivating group members or employees, and access to Islamic Financial Service Cooperative or government agencies. To what extent the empowerment micro enterprise model after obtaining financing of Islamic Financial Service Cooperative.

\subsection{The focus of research}

This study focused on: The role of Islamic Financial Service Cooperative in empowering micro enterprises that discription in depth about how financing disbursed of Islamic 
Financial Service Cooperative to micro enterprises able to empower micro enterprises namely in terms of the ability of capital, the ability of technology, modern management, motivating group members or employees, and access to Islamic Financial Service Cooperative or government agencies, and employment. As well as the ability to issue a financing.

\subsection{Sources and types of data}

All the data are retrieved from the data base on the Islamic Financial Service Cooperative with some sources stating Islamic Financial Service Cooperative is Islamic microfinance institutions that about $70 \%$ of financing channeled to micro enterprises.

Sources and types of research data obtained in the following manner:

- key informants (key informants) consists of:

1. Leadership Islamic financial service cooperative along with the head of the financing.

2. micro entrepreneurs are receiving financing under 50 million rupiah $(\mathrm{BI}$, 2015).

\section{- Supporting Data}

Data supporting of this research is related to Islamic financial service cooperative news from the media, seminars, Central Bureau of Statistics, Department of Cooperatives, internet journals, and other sources related.

\subsection{The data collection process}

In qualitative research, the data collection process to move from empirical field in an attempt to build a model of data.Data collection process includes the following stages:

- The process of entering the study sites (getting in)

In this stage the researchers met the parties who are competent in providing explanations related to the problem under study.

- Being on location (getting along)

In this phase, researchers establish personal relationships with research subjects, searching for complete information needed as well as express the meaning of information and observations obtained. 
- Data collection (Data Logging)

In this phase, data collection technique used is In-depth interviews (in depth interview) that perform depth interviews with key informants or research subject.

\subsection{Data analysis and interpretation process}

Analysis of the data used in this research is qualitative descriptive analysis. Interpretive process used is identifying financing of Islamic Financial Service Cooperative -financing channeled to the micro enterprises. After that describes in depth how the financing of Islamic Financial Service Cooperative role in the process of empowering micro enterprises until completion of the empowerment model of micro-enterprises financed by Islamic Financial Service Cooperative.

\section{Result and Discussion}

\subsection{Fulfillment of capital requirements}

The entire micro-business, both in Indonesia and in Malaysia, indication the importance of fulfilling the needs of the capital. Without capital they would not able to maintain and develop its business. Prijadi (2017) says bank loan drives profitability and Smash sales higher, although collateral limits the growth. IFSC presence in two countries greatly assist sustainability microenterprises. Load a lighter margin than interest expenseson a conventional bank or rentener, is an excess of owned IFSC and indispensableby microbusiness ventures. IFSC financing majority distributed in murabahah contract greatly help the sustainability of microenterprises. But the more expected is financing with the contract besides murabahah, in example mudharabah or musyarakah and the most important is fulfilled its financing needs.

\subsection{Indicators of motivation of group members}

Well on micro enterprises in Malaysia nor Indonesia, mostly micro enterprises that existed was the effort to be able to motivate the members of his group, or fellow entrepreneurs in the same line of business, or the eager employees to promote his business. In line with research (Yaacob, 2015) that declares jihad commerce business achievement affect Muslims. Motivation is important, especially in the face of the failure of the businesses that are most likely to occur and also for grabbing business 
opportunities, in order that progress is achieved. The results of this research indicate all types of micro enterprises funded by IFSC and managed memepertahankan its continuity, they have done the motivation against fellow business associates as well as workers in developing his business. For micro enterprises in Indonesia, the majority of them independently motivates his group without assisted IFSC as well as government agencies. But for Malaysia, instead they mutually motivate between entrepreneurs as well as the Government's very high concern related motivating micro enterprises.

\subsection{Access to the goverment}

Micro is good should be able to connect their business with the Government and other financial institutions. This access is important not only in the matter of funding but also in the strained relations with other agencies, especially in getting information that is essential for the progress of micro enterprises, for example in marketing. Iskandar (2017) States the role of a weak Government, will hinder the development of micro enterprises. The results of this research indicate all types of businesses primarily micro enterprises either in Indonesia or Malaysia has been getting funding with an easy process from IFSC. Conditions in Indonesia, associated access to government agencies such as the Department of cooperatives and SMEs as well as Disperindag, then most types of micro businesses haven't been able to execute it. In contrast with Malaysia, the Government is actively contacting micro enterprises, so that they are able to establish rapport with government agencies as well.

Based on the above analysis, the link between IFSC and it function in realization of economic prosperity and sustainability of micro, can be seen in the model below, where this model explains that economic functions performed by IFSC in empowering micro businesses both in Indonesia as well as Malaysia is to meet the needs of venture capital groups, motivating micro micro businesses and provide high accessibility to the Government, and also against other institutions nor IFSC related. The third aspect of this will be to enable the institution as IFSC able to empower and realizing sustainability of micro enterprises, as a model below.

Other findings from this research is both in Indonesia as well as Malaysia, on the important presence of micro enterprise facilitation efforts. Micro States mentoring beginning as submission funds financing is useful to motivate utilizing funds productively. Guidance provided submission funding since the beginning of the IFSC motivating micro enterprises to use the funds with full responsibility, among others, affirming the establishment to use funds for productive activities or business, and are not allocated 


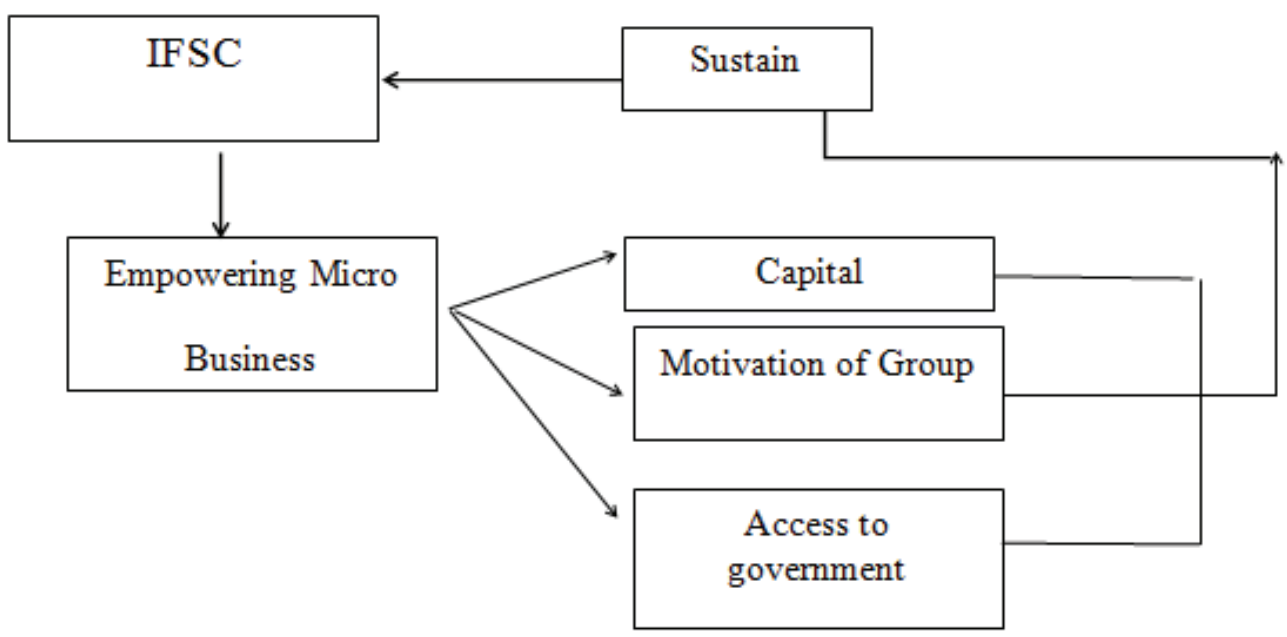

Figure 1: The empowerment model of micro enterprises by IFSC.

to it the others, or that is consumerist. Mentoring at the time the customer pays in installments, is very important, so that micro enterprises sincrely, discipline in pay installment financing. At this time the IFSC party can do with more intensive mentoring, among others by asking the development efforts, as well as providing clinical effort.

The results of this research show the micro gets the mentoring, will be motivated to do business with good and professional, the partnership, in the form of a familiar relationship between the IFSC with the customer. The efforts of IFSC to invite micro, join the feel to have the IFSC, among others, realized after the loan paid off, then the client or micro businesses will voluntarily take on the financing of the IFSC, as found by taking the financing then not only this instrumental in the development of its business, but also develop the IFSC.

\section{Conclusion}

Based on the data and the results of the analysist has been done then the conclusion to be drawn as follows: Similarities conditions between Indonesia and Malaysia are the other related roles of the IFSC has reduced the loss of community that stuck the money lenders. Besides, it can also be examined from the financing process is distributed to both members and non-members or the ccommunity around the IFSC, that the majority of the financing distributed is murabaha contract, and a bit on mudharaba contract. More focus is empowering micro businesses, among others from free from money lenders, giving motivation to group members,build access to the IFSC or related 
institutions. The differences between Indonesia and Malaysia microfinance empowerment is the intensity of the attention of the Government in providing access or opportunities to microenterprises. Malaysia is more intense, so that microenterprise is easier access to the Government, and other institutions, easy to get funds and other facilities. Other findings are a form of mentoring on micro enterprises. Microenterprises that get mentoring at the time of repayment, will be motivated, to the discipline of paying installments, and also to motivate, to earnest in doing business. The clinic's efforts will impact significantly on effort to keep the sustainability. Mentoring at the time of repayment will encourage micro enterprises that got financing IFSC, to develop business sustainability.

\section{References}

\section{Journal Article}

[1] Ascarya. (2004). Identifikasi Masalah Rendahnya Pembiayaan Bagi Hasil. Jakarta: Pusat Studi dan Pendidikan Kebangsentralan BI Jakarta

[2] Ascarya, Diana Yumanita, Ahmad Arief. (2004). Domonasi Pembiayaan Non Bagi hasil di Perbankan Syariah Indonesia. Jakarta: Pusat Studi dan Pendidikan Kebangsentralan BI Jakarta

[3] Bank Indonesia. (1998). Undang-Undang No.7 Tahun 1992 tentang Perbankan sebagaimana telah diubah dengan Undang-Undang No.10 Tahun 1998. Jakarta: Direktorat Hukum Bank Indonesia.

[4] _ (2011). Statistik Perbankan Syariah Indonesia. Berbagai Edisi. Jakarta: Direktorat Perbankan Syariah Bank Indonesia.

[5] . Online Site: www.bi.go.id. Diakses tanggal 14 Maret 2017.

[6] _ (2016). Statistik Perbankan Syariah Indonesia. Berbagai Edisi. Jakarta: Direktorat Perbankan Syariah Bank Indonesia.

[7] Iskandar Takiah Mohd, Nor Hazwani, Zuraidah Mohd Sanusi, Zakiah Muhammadun Mohamed. (2017). Board of Directors and Ownership Structure: A Study on Small and Medium Enterprises (SMEs) in Malaysia. Jurnal Pengurusan 49(2017) 25 - 39

[8] Janoor, Mohd. Hafizuddin Syah Bangaan Abdullah Hawati, Mohamad Abdul Hamid, Puan Yatim. (2017). The Effect of Enterprise Risk Management on Firm Value: Evidence from Malaysian Technology Firms (Kesan Pengurusan Risiko Enterpris ke atas Nilai Firma: Bukti dari Firma-Firma Teknologi di Malaysia). Jurnal Pengurusan 49(2017) $3-11$ 
[9] Lukytawati, Anggraeni. (2010) Pembiayaan Usaha Mikro berbasis Masjid Studi Kasus BMM. Jurnal ekoniomi Islam Republika. 4 Nopember 2010

[10] Prijadi. (2017). Board of Directors and Ownership Structure: A Study on Small and Medium Enterprises (SMEs) in Malaysia (Ahli Lembaga Pengarah dan Struktur Pemilikan: Kajian Perusahaan Kecil dan Sederhana (PKS) di Malaysia). Int. Journal of Economics and Management 11 (S1): 35 - 44 (2017)

[11] Yaacob, Yazilmiwati, Ilhaamie Abdul Ghani Azmi. (2015). Hubungan Jihad Perniagaan dengan Pencapaian Usahawan Muslim Berjaya di Malaysia (Examining the Relationship Between Business Jihad and the Achievement of Successful Muslim, Jurnal Pengurusan 44(2015) 81 - 91

\section{A Book}

[12] Ryandono, Muhammad Nafik H. (2009). Benarkah Bunga Haram?. Surabaya: Amanah Pustaka

[13] Zulkifli, Sunarto. (2003). Panduan Praktis Transasksi Perbankan Syariah. Jakarta Timur: Zikrul Hakim

\section{Thesis}

[14] Ryandono, Muhammad Nafik H. (2010). Peran Dan Pengaruh Penghimpunan Dana Terhadap Penyaluran Dana Dan Faktor Kinerja Bank Serta Kesejahteraan Bank Islam di Indonesia. Disertasi Program Doktor. Universitas Airlangga, Surabaya, Indonesia. 